\title{
A population study of tropical Peregrine Falcons (Falco peregrinus ernesti) in West Malaysia
}

\author{
Beng Yean Ooi ${ }^{1}$, Marc Kéry ${ }^{2}$, Robert Percival ${ }^{3}$, Zan Hui $\mathrm{LeE}^{4} \&$ \\ Sein Chiong CHIU ${ }^{5}$
}

Received: February 29, 2020 - Revised: March 20, 2020 -Accepted: March 21, 2020

Ooi, B. Y., Kéry, M., Percival, R., Lee, Z. H. \& Chiu, S. C. 2020. A population study of tropical Peregrine Falcons (Falco peregrinus ernesti) in West Malaysia. - Ornis Hungarica 28(1): 1127. DOI: $10.2478 /$ orhu-2020-0002

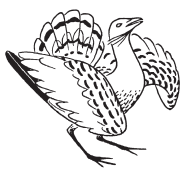

Abstract The Peregrine Falcon (Falco peregrinus) is the most widely distributed bird species in the world, but very little is known about its tropical populations, where even very basic information (e.g. about population density) is mostly lacking. In January 2017, 2018 and 2019, we conducted three intensive surveys amounting to 27 days and 5,400 km driven by car in West Malaysia at latitudes between 3 and $7{ }^{\circ} \mathrm{N}$, where the ernesti subspecies was confirmed to be a resident breeder only as recently as 1996 . Here, we summarize our findings and combine them in a synthesis that includes all published and unpublished records of nesting peregrines that we could obtain in that area. In particular, we draw on the foundational work conducted by our late colleague Laurent Molard in 2003-2005. We give information about breeding habitats, local density, behavior and breeding phenology. We also describe and discuss our use of call playback during the surveys. Much more extensive reports for each survey, with plenty of photographs of all sites visited, are available upon request from the authors.

According to current knowledge, Peregrines in West Malaysia nest mainly in cliffs, with some nesters on buildings exceptionally found (in Kuala Lumpur and suspected also elsewhere in cities) and possibly on large towers. Virtually all natural nesting places are limestone mountains with vertical cliffs. Owing to the mostly flat terrain in West Malaysia, with limestone cliffs only occurring very locally, the peregrine breeding distribution is extremely patchy. We found local aggregations in the regions of Ipoh (Perak), Gua Musang (Kelantan) and in the state of Perlis. However, local density is fairly low even in these hotspots, with nearest-neighbor distances in the densest cluster ranging from 3.7-5.6 km (mean 4.7). Overall, by the end of 2019, 36 occupied sites had been found in West Malaysia, of which 10 were known before 2003, 9 were found during the surveys by Molard and his colleagues in 2003-2005, and 17 were new discoveries during our surveys in 2017-2019. In West Malaysia, the start of egg-laying appears to be late January and early February. We found playback of the 'eeechup' courtship calls to be extremely helpful when locating pairs. Playing a 26 -sec sequence twice enticed the majority of birds to become airborne and/or to call, which greatly increased their detection probability and therefore survey success.

In spite of the great increase in the number of known peregrine sites owing to our surveys, the currently known number of pairs is still considerably lower than the estimate by Molard et al. (2007) of 70-80 pairs. Although this latter may perhaps be a slight overestimate, we are convinced that many more pairs remain to be discovered in cliffs, where most of the future survey effort should be concentrated. This will then also provide the basic knowledge required to protect limestone outcrop sites, e.g. from quarrying activities, which may destroy entire limestone hills. However, we believe that the major uncertainty about the size of the population of nesting F. p. ernesti in Malaysia arguably comes from the population segment of nesters on buildings, which is likely underestimated and hard to survey and even discover in the first place. Moreover, given the rate of increase of nesters on buildings in other parts of the world, it is likely that the proportion of pairs nesting on buildings will increase also in Malaysia. Hence, we believe that new pairs will be discovered in the future also where there were none in earlier years. 
Összefoglalás A vándorsólyom (Falco peregrinus) a világ legelterjedtebb madárfaja, azonban nagyon keveset tudunk a trópusokon élő populációiról, sokszor még az alapvető információkkal (pl. állománysürúség) sem rendelkezünk. 2017-ben, 2018-ban és 2019 januárjában három felmérést végeztünk, amelyek során 27 napon át 5400 kilométert tettünk meg Nyugat-Malajziában, az északi szélesség $3^{\circ}$ és $7^{\circ}$-a között, ahonnan az F. p. ernesti alfaj csak 1996-ban lett leírva, mint állandó fészkelő faj. Jelen cikkben összegezzük az eredményeket, egyúttal bemutatjuk az általunk fellelt, a területen fészkelő vándorsólyom párokról publikált, és eddig még nem közölt adatokat, különös tekintettel néhai munkatársunk, Laurent Molard 2003-2005 között végzett munkájára. Bemutatjuk a fészkelésre használt élőhelyeket, a helyi állománysürüség, viselkedés és költésfenológia adatokat. Ismertetjük és tárgyaljuk továbbá a felmérésekhez használt hanglejátszási módszert. Kérésre a szerzők jóval részletesebb leírást tudnak adni az egyes években végzett felmérésekröl, sok fényképpel kiegészítve.

A jelenleg rendelkezésre álló információk alapján Nyugat-Malajziában a vándorsólymok jellemzően sziklafalakon, kivételes esetben épületeken (Kuala Lumpurban és feltehetően más városokban is) és valószínüleg magas tornyokon fészkelnek. Az összes természetes fészkelőhely mészkőhegységek függőleges sziklafalain található. Mivel Nyugat-Malajzia alapvetően sík, és a mészkőhegyek elszórtan találhatók, a fészkelő vándorsólyom párok elterjedése meglehetősen szigetszerü. Kisebb helyi fészkelőpár-csoportosulásokat találtunk Ipoh (Perak), Gua Musang (Kelantan) régiókban és Perlis államban. A helyi állomány sủrúsége azonban még ezeken a helyeken is alacsony, a legsúrübb állományokban is, a legközelebbi szomszédtól való távolság 3,7-5,6 km (átlagosan 4,7 km). Összességében 2019 végéig 36 aktív revírt találtunk Nyugat-Malajziában, amelyből 2003 elött tíz volt ismert, kilencet Molard és kollégái találtak a 2003-2005-ös felmérés során, 17 revírt pedig a mostani 20172019-es kutatásaink során fedeztünk fel.

Nyugat-Malajziában a tojásrakás kezdete január vége - február eleje. A vándorsólyom nászrepülési időszakban hallatott „í-csup” hívóhangjának lejátszását különösen hasznosnak találtuk a fészkelő párok keresése közben. Egy 26 másodperces hangfelvétel kétszer ismételt lejátszása a madarak többségét arra késztette, hogy a levegőbe emelkedjen, ezzel jelentősen növelve a felderítés sikerét.

Annak ellenére, hogy kutatásaink eredményeképpen jelentősen nőtt az ismert párok száma, a jelenleg ismert állomány nagysága lényegesen elmarad Molard és munkatársai (2007-es) becslésétöl, amely 70-80 párra teszi a párok számát. Bár ez a becslés kissé túlzónak tủnik, meg vagyunk győződve arról, hogy sok fészkelö pár vár felfedezésre a sziklafalakon, amelyekre a jövőbeni kutatásoknak összepontosítaniuk kell. Ez utóbbiak azokat az alapvető információkat is meg fogják adni, amelyekre a mészkő-sziklafalak - például az egész mészkőhegyeket eltüntető mészkő-bányászat elleni - védelméhez szükség van. Úgy véljük azonban, hogy az állománynagyság becslésében a legnagyobb bizonytalanságot az épületeken fészkelő párok okozzák, amelyek száma valószínüleg alulbecsült, és amely párok számát rendkívül nehéz felmérni, vagy egyáltalán felfedezni őket. Emellett, figyelembe véve az épületen fészkelő párok számának növekedési ütemét a világ más részein, valószínü, hogy az épületen fészkelő párok aránya Malajziában is emelkedni fog. Úgy véljük ezért, hogy a jövőben olyan helyeken is meg fognak jelenni új párok, ahol eddig nem voltak jelen.

Kulcsszavak: fészkelő állomány sűrüsége, Falco peregrinus ernesti, Malajzia, vándorsólyom, állománysűrűség, trópusok

\author{
${ }^{1}$ 182, Jalan Raja Kam, Taman Canning, 31400 Ipoh, Negeri Perak, Malaysia (†) \\ ${ }^{2 *}$ Swiss Ornithological Institute, 6204 Sempach, Switzerland (marc.kery@vogelwarte.ch) \\ 3 1, Lintasan Taman Tambun, 31400, Ipoh, Perak, Malaysia (robert.pval@gmail.com) \\ ${ }^{4}$ School of Environmental and Geographical Sciences, University of Nottingham Malaysia, Semenyih, Malaysia \\ (zanhui96@gmail.com) \\ 543, Lorong Gopeng, Taman Golf.31350, Ipoh, Perak, Malaysia (chiusch@gmail.com) \\ * corresponding author
}




\section{Introduction}

Despite a large number of population studies dedicated to the Peregrine Falcon (Falco peregrinus), extremely little is known about this fascinating species in the tropical parts of its worldwide breeding distribution, which comprises parts of tropical South America, Africa and Madagascar, India, Sri Lanka, South-East Asia and Australia (White et al. 2013). Only a small handful of studies on tropical peregrines have been published, but even very basic information about distribution, population density and fecundity (i.e. some of the most commonly recorded quantities in raptor population studies) is for the most part lacking for these truly vast areas. Some exceptions include Kéry (2002), who summarized the known distribution for F. p. cassini in Peru, and then especially Hermann Döttlinger's studies of F. p. peregrinator in Sri Lanka (Döttlinger \& Hoffmann 1999, Döttlinger et al. 1999, Döttlinger 2002, Döttlinger \& Nichols 2005). Laurent Molard and his colleagues (2005, 2007 and 2009) report on their studies in West, i.e. mainland, Malaysia, and describe the known distribution and breeding phenology of $F$. p. ernesti, the darkest peregrine subspecies in the world (Figure 1).

The F. p. ernesti subspecies has been known to nest in Malaysia from a single instance of confirmed breeding in 1996 (Chong 2002), although other observations of pairs during the breeding season at two sites in the Kuala Lumpur metropolitan area made breeding likely already during the 1980s. Further confirmed breeding records were then obtained just after the turn of the century (Molard 2005, Chiu et al. 2006). The first synthetic overview of the knowledge on breeding peregrines in Malaysia was the unpublished report compiled by Molard (2005). It contained information that was collected by Laurent Molard and was augmented with observations from his colleagues and with information gleaned from the published literature. Molard's 2005 report lists 15 sites in the states of Selangor, Pahang and especially in the Ipoh area of Perak. Based on this information and including later observations, Molard et al. (2007) then went on to make an educated guess of the possible number of peregrine breeding pairs in the $135,000 \mathrm{~km}^{2}$ of West Malaysia and arrived at 70-80 pairs, essentially in the centre and north of the country (see also Molard 2009). Based on the known or suspected 24 territories and that projection, a density of only $0.02-0.06$ pairs per $100 \mathrm{~km}^{2}$ was estimated. This suggests that the peregrine is a fairly widespread, but overall extremely rare breeding bird in Malaysia. During the 10 ensuing years, no other syntheses on resident peregrines in Malaysia have been compiled, but local observers, especially Chiu, Connie Khoo, and some of their colleagues in the Ipoh area, continued to watch peregrines during the breeding season at several sites in that region.

Most parts of West Malaysia are flat and devoid of any rocky outcrops, or they are mountainous, but with old, eroded hills, which also for the most part are devoid of any cliffs. Therefore, the scope for cliff-nesting peregrines is extremely limited in Malaysia. Essentially, the species seems to be restricted to limestone country, where natural cliffs occur and sometimes quarry activities create new, albeit sometimes only ephemeral, cliff faces. The Malaysian economy is growing fast, and hence as in many other countries of SE Asia, there is a huge demand for cement. The latter is produced in quarries that may eventually destroy entire limestone outcrops and the peregrine nesting sites along 

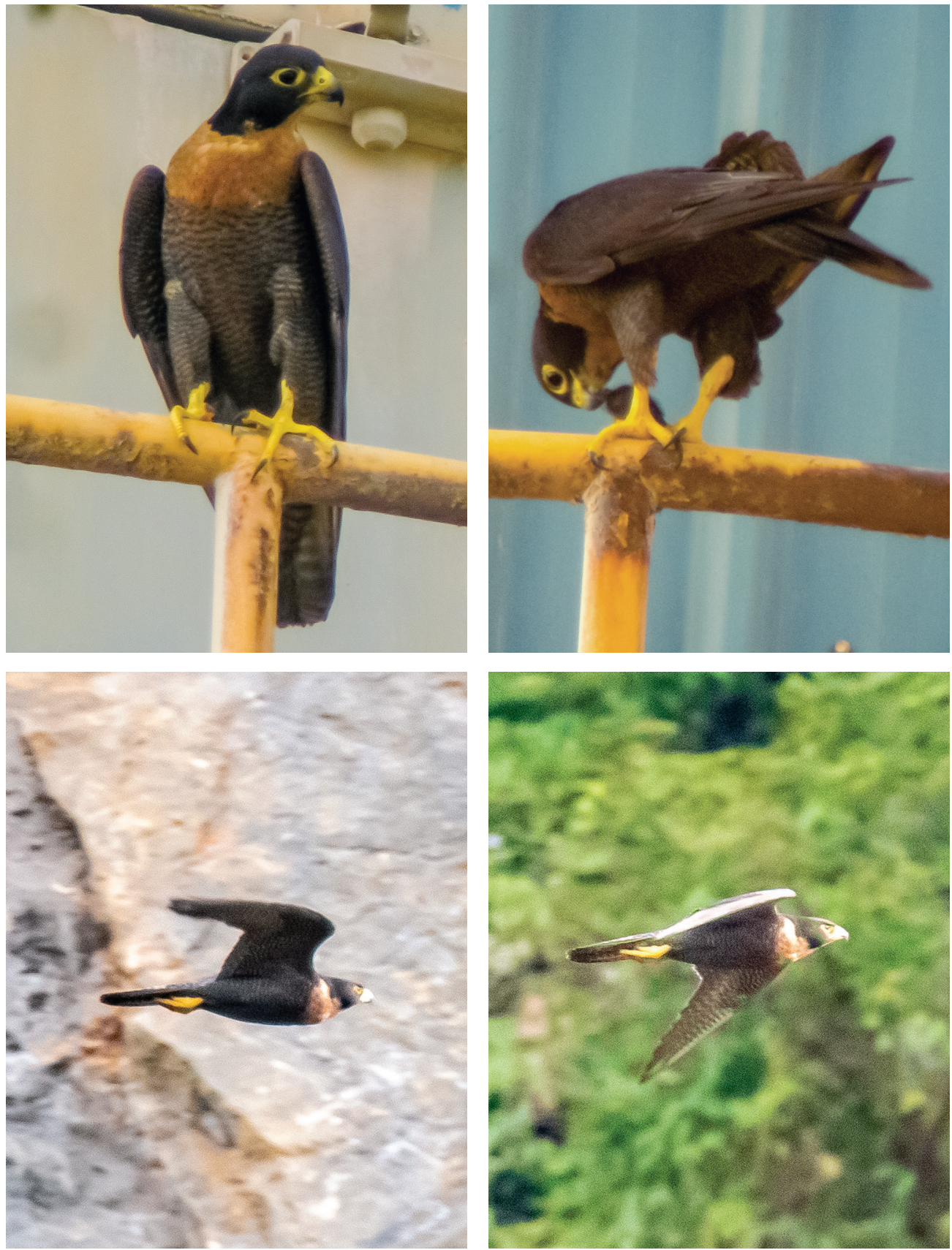

Figure 1. Several photographs of F. p. ernesti in our study area. Especially in flight, this subspecies can look almost black when viewed from a distance and overall sometimes looks like a species altogether different from Falco peregrinus! Photos: Beng Yean Ooi

1. ábra Néhány, a vizsgálati területen készült fotó az F. p. ernesti alfajról. Ez az alfaj különösen repülése közben, messziről megfigyelve szinte teljesen feketének tűnik, és összességében néha olyan, mintha egy teljesen másik fajhoz tartozna 
with them. Therefore, there is a pressing scientific and conservation need to advance our knowledge about this bird in Malaysia. Scientific, since this is one of extremely few tropical regions where knowledge about basic population parameters such as breeding density and productivity has started to accumulate for the peregrine, and conservation, because a good knowledge about distribution and abundance of a species is the obvious, first basic requirement for its conservation.

Between 2017 and 2019, we conducted three surveys in West Malaysia during the courtship period and tried to visit as many of the previously known sites and discover as many new sites as possible (Kéry et al. 2017, 2018, Ooi et al. 2019). Our goal was to improve our knowledge about breeding distribution, habitat and density of $F$. p. ernesti in this area. In addition, we compiled an Excel database with all known peregrine sites in West Malaysia, drawing on published and unpublished literature as well as on oral communications from friends and colleagues. Based on this, we here give a new synthesis of what is currently known about $F$. p. ernesti as a breeding species in West Malaysia. We build in part on the foundation laid by Laurent Molard (Molard 2005, 2009, Molard et al. 2007), but here, we do not attempt to produce a new national population size estimate.

\section{Methods}

\section{Field work}

We conducted three field surveys on 8 days between 6 and 19 January 2017, on 9 days between 17 and 25 January 2018, and on 10 days from 21-30 January 2019 and covered a total of approx. 5,400 km by car (Figure 2). Before the field work, we studied the locations of all previously known peregrine sites in the covered areas on Google Earth and Google Maps. During the surveys, we used GPS as well as aerial photographs in Google Earth and Google Maps to navigate to the vicinity of some of the cliffs on dirt tracks through oil palm plantations and other habitats that were difficult to overlook from the ground. We used a

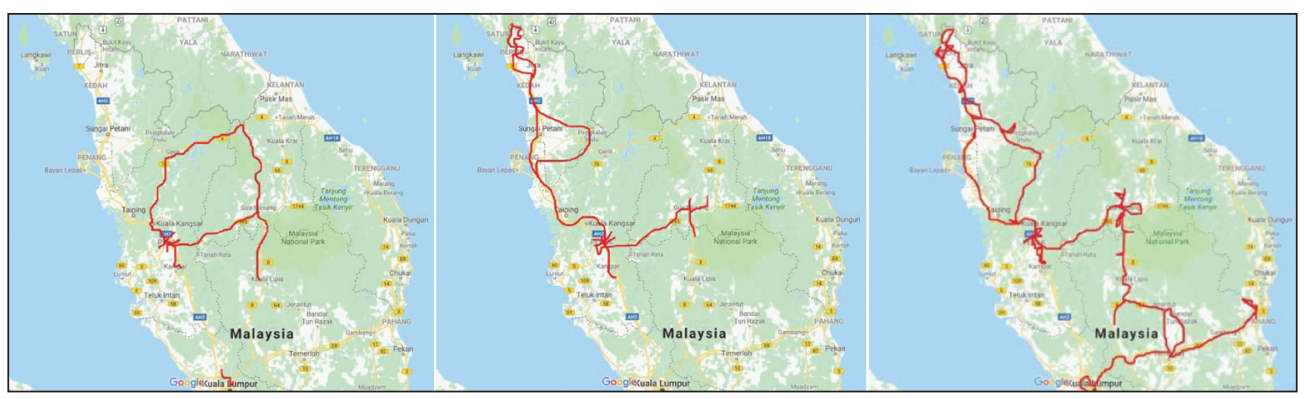

Figure 2. Trajectories of the three Peregrine Falcon Surveys in 2017 (left), 2018 (middle), and 2019 (right), with approx. total lengths of $800,1,600$, and 3,000 kms, and during which we checked 22, 36, and 68 known or potential peregrine sites

2. ábra A három vándorsólyom felmérés útvonala: 2017. év (balra), 2018. év (középen) és 2019. év (jobbra), megközelítőleg 800, 1600 és 3000 megtett kilométer, 22, 36 és 68 ismert vagy feltételezett vándorsólyom előfordulás 
Toyota Hilux pickup, which was invaluable to get sufficiently close to many of these sites, so that observations could be made of the birds and playback calls could be broadcasted at an adequate range with any hope of success (see below). That is, closer than about $1 \mathrm{~km}$ and ideally also closer than $500 \mathrm{~m}$ to the main cliff where peregrine occupancy was known or suspected.

To check a known territory or a likely new site for peregrines, we usually placed ourselves as close to the site as possible, at the base of the cliff, while trying to maximize the view of the sky around the cliff. Observations were made with the naked-eye, with 8-10× binoculars and 20-60× telescopes mounted on a tripod. Key elements of such surveys in the courtship period were the naked-eye scanning for flying birds of the upper edge of the cliff or of the crest of the mountain in which a cliff is located and acoustic attention for the frequent calls. When a cliff was very high and/or steeply above the observation point or when watching birds flying overhead, the best observation position was often found to be flat on one's back (best with a blanket and a pillow, although a nicely browsed pasture could also serve).

In addition, the use of binoculars and telescopes for checking of the cliff for perched birds and for whitewash was also always an important part of the survey at every cliff. Especially during courtship, birds perch actually more often in the first trees just at the top of the cliff, or also in trees within the cliff face, rather than directly on a rock in the cliff itself (MK, pers. obs.). Hence, painstakingly checking all cliff-top trees was particularly important when surveying for peregrines during this stage of the breeding cycle. In West Malaysia, the peregrine appears to be the major moderate to large species which produces whitewash, hence looking for whitewash in a cliff was also an important part of our surveys (but see also Discussion).

Sites were visited between about $8.00 \mathrm{~h}$ in the morning and $19.30 \mathrm{~h}$ in the evening. Observation periods per site lasted typically about 1 hour, though sometimes they were shorter, e.g. 30 minutes or even less for some of the less-promising-looking cliffs. Sometimes, we spent 2-3 or even more hours at a cliff. The presence of several observers was very beneficial, since it increased the probability of bird detection, especially when they were not calling.

There are several subspecies of the peregrine occurring in Malaysia (White et al. 2013): the resident subspecies is usually attributed to $F$. $p$. ernesti, while in the boreal winter, birds of the japonensis or similar subspecies from NE Asia can be found wintering in the country as well. These subspecies can be differentiated quite easily from the locally breeding one, since F. p. ernesti is the darkest subspecies in the world (see Figure 1), while the peregrines breeding in NE Asia are typically far lighter, with thinner moustaches etc. All birds that we discovered belonged to the locally nesting $F$. $p$. ernesti subspecies.

\section{Use of playback calls}

During the 2019 survey we made frequent use of playback calls to increase the detection probability of the birds at a site (Barnes et al. 2012, Ambrose et al. 2014). Unless both birds were detected early during a watch, we often used playback of the 'eee-chup' call (Ratcliffe 1993) from a pair using a FoxPro game call portable amplifier. This mimics the calling of 
an intruding pair. We used an eee-chup recording lasting 26 seconds from Xeno-canto (see https://www.xeno-canto.org/357721), which is from a pair recorded on 4 March 2017 in the middle of the Brazilian Amazon where no peregrines are known to nest; therefore, it must be from wintering birds originating from the boreal or arctic parts of North America. We repeated this recording between 1-6 times (though, usually only twice) at a site, that is, for a total of approx. 30 seconds to under 3 minutes. As soon as both birds were detected, we stopped broadcasting the call so as to minimize disturbance.

\section{Collation of other information and literature records}

We tried to source as many records as possible of potentially nesting peregrines in West Malaysia, either from the literature, but also from personal communications, either directly or indirectly to one of the authors. We have created an Excel data base which lists (at the time of writing) 94 cliff objects in West Malaysia, drawing on all the information in Molard (2005), Molard et al. (2007) and on our three surveys combined and on all other information that we could obtain.

\section{Results}

\section{Breeding habitat of $F . p$. ernesti in Malaysia}

With the single exception of one breeding pair on a building found by Molard in Kuala Lumpur in 2004 (Molard 2005), all peregrine territories found so far in West Malaysia were in cliffs in limestone hills. While the smallest of these cliffs were exceptionally only $20-30 \mathrm{~m}$ tall, the vast majority was much taller and reached about 300 metres and more for the tallest of them. Overall, we got the impression that Malaysian peregrines have an even greater tendency to only nest in the tallest available cliffs than in other places of the world where the second author has observed them, e.g. North and South America, Europe and Australia.

\section{State of knowledge on F. p. ernesti in West Malaysia up to 2005}

The first confirmed nesting pair in Malaysia was found as late as 1996 (Chong 2002), although Wells (1990) mentioned an observation of a copulating pair in Bukit Takun on the outskirts of Kuala Lumpur in 1984, and pairs had also been recorded in the 1980s at the Batu Cave limestone hill in the Kuala Lumpur metropolitan area. There was also an early record from Bukit Air Jernih in the 1990s (Molard et al. 2007). The first breeding pairs in the Ipoh area were found in 2004 (Molard 2005, Chiu et al. 2006). Also in 2004, an unsuccessful breeding attempt was recorded on a tall hotel building in downtown Kuala Lumpur (Molard 2005). So far, this appears to remain the only confirmed nesting on a building in the country, in spite of suspicious sightings of $F$. p. ernesti birds in several cities including Penang (Ho Khee An, pers. comm. to Chiu) and also on transmission towers in several 
places including near Gerik (Lee, pers. obs.) and in the Genting Highlands (Molard 2005). Before Molard's field work during 2003-2005, 10 peregrine territories were known in West Malaysia; he then found 9 new ones, bringing the total to 19 (Figure 3).

\section{Major results from our 2017 survey}

We visited nine sites that were previously known to hold peregrine territories and 20 additional sites about whose status as a peregrine cliff nothing was previously known. We detected peregrines at 11 sites: a pair at 8 and a single bird at 3 sites. Eight sites were previously known territories and 3 were newly detected ones, bringing the total number of peregrine sites known in West Malaysia to 22 (Figure 3). One of the new territories, in a quarry near the city of Ipoh, was only about $2 \mathrm{~km}$ from a previously known neighboring territory. This was much closer than the previously known closest nesting pairs in Malaysia. Although this new pair could not be confirmed again afterwards, this observation emphasized the need to take into account the possible nesting of adjacent pairs at much closer distances than what was previously thought (e.g. at $2-4 \mathrm{~km}$ ).

\section{Major results from the 2018 survey}

We surveyed 36 sites in total. Fourteen sites were in the region of Ipoh (Perak), 11 sites around Gua Musang (Kelantan, including one site in adjacent Pahang), three sites in Kedah and eight sites in Perlis (including one in adjacent Thailand). Nine of the 36 sites were previously known peregrine territories and we found peregrines at 7 (78\%) of them, while we did not find any birds at $2(22 \%)$. Five new peregrine sites were discovered, thus bringing the known total in West Malaysia up to 27 (Figure 3).

\section{Major results from the 2019 survey}

We surveyed a total of 68 cliffs of which 18 were previously known as peregrine territories. Of these, 17 were confirmed to be occupied by at least a single peregrine, while we did not find any birds at one of these sites. We discovered 9 new sites that had not been known before and re-discovered 2 pairs that had moved to new cliffs, where they had never been seen before. Overall, during our 2019 surveys we found a total of 28 occupied sites: at 25 sites we observed adult pairs, while at 3 sites, only single birds could be detected. At the end of our 2019 survey, the known total sites in West Malaysia stands at 36 (Figure 3).

For these 68 checked cliffs with their 28 occupied sites, Table 1 gives a breakdown by state and shows the percentage of occupied cliffs among the checked ones. The number of checked cliffs broadly provides a crude measure of how common suitable-looking cliffs are in each state, being most common in the surveyed parts of Perak and Kelantan, and also common in Perlis, least common in Selangor and Kedah and intermediate in Pahang. However, the percentage of occupied cliffs (excluding Selangor with its single checked cliff) was greatest in Pahang, where many of the cliffs were isolated from each other and tall, intermediate in Perak and Kedah and lowest in Kelantan and Perlis. 


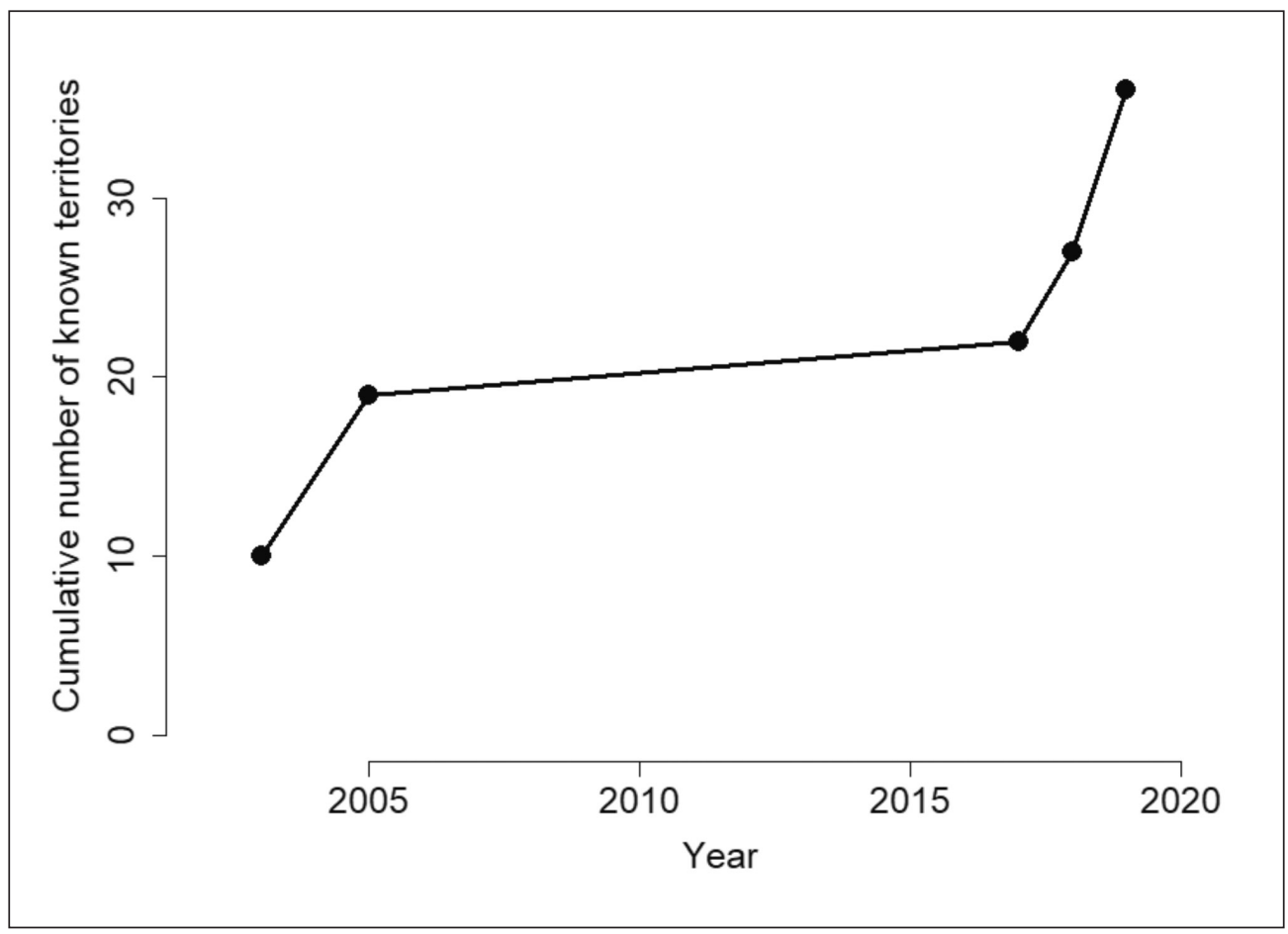

Figure 3. Cumulative number of known peregrine territories in West Malaysia before the surveys of Molard (in 2003), including the surveys of Molard (up to 2005) and at the completion of our surveys in 2017, 2018 and 2019

3.ábra Az ismert vándorsólyom territóriumok összesített száma Nyugat-Malajziában Molard felmérései előtt (2003), beleértve Molard 2005-ig végzett felméréseit és az általunk 2017ben, 2018-ban és 2019-ben befejezett felméréseket

Table 1. Number of checked and occupied cliffs per state in the 2019 survey

1. táblázat Az ellenőrzött és elfoglalt sziklák száma régiónként a 2019-es felmérés során

\begin{tabular}{|l|c|c|}
\hline \multicolumn{1}{|c|}{ State } & Number of cliffs checked & Occupied (\%) \\
\hline Selangor & 1 & $1(100 \%)$ \\
\hline Pahang & 11 & $7(64 \%)$ \\
\hline Perak & 19 & $9(47 \%)$ \\
\hline Kelantan & 19 & $5(26 \%)$ \\
\hline Kedah & 4 & $2(50 \%)$ \\
\hline Perlis & 14 & $4(29 \%)$ \\
\hline Total & 68 & $28(41 \%)$ \\
\hline
\end{tabular}




\section{Distribution of nesting peregrines in West Malaysia}

The currently known distribution of 36 peregrine sites in West Malaysia is extremely uneven and reflects the availability of vertical rocky outcrops (see Figure 4). As already noted by Molard et al. 2007, the three major concentrations of nesting peregrines are the cliff-rich regions around Ipoh/Perak in the centre West, Gua Musang/Kelantan in the centre, and the state of Perlis in the North.

\section{Breeding phenology}

All our field observations supported the previous notions (Chiu et al. 2006, Molard et al. 2007) that the start of egg-laying in our study area is around the end of January and in early February. During our January surveys, we observed plenty of courtship behavior, including many copulations. We never could observe an incubating bird, but this would have been impossible at most sites because the eyries were either too high up or too deep in a karstic pothole. However, during the 2019 surveys we surmised that incubation had started from the behaviour of several pairs.

\section{Population trends}

During all our surveys, we re-visited a large proportion of the previously known territories. Typically, we found most of them to be occupied; see above. From this we would tentatively conclude that the population is most likely stable, or possibly even increasing.

\section{Results on our experimentation with call playbacks}

We had tremendous success with our short playback sessions of the calls from an eee-chupping peregrine pair plaid from a portable playback machine at most of the surveyed sites: even at the tallest cliffs and at distances of up to almost 1000 metres, the pair often became airborne after 36-52 seconds (i.e. during the first two times our recording was played), calling a lot and thus permitting efficient confirmation of an occupied site. Among the 28 sites that were found to be occupied during the 2019 survey, birds were first detected without playback at $10(36 \%)$, while birds were first detected after playback at the remaining $18(64 \%)$.

\section{Discussion}

More than a decade after Molard et al. (2007), this article provides a new synthesis on what we currently know about resident, nesting peregrines of the subspecies $F$. p. ernesti in West Malaysia. We describe the results of three surveys during the courtship periods 2017-2019 totaling 27 days and 5,400 km driven by car, and we amalgamate our field records with all information that we could obtain on potentially nesting peregrines in this area. Here, we put our 


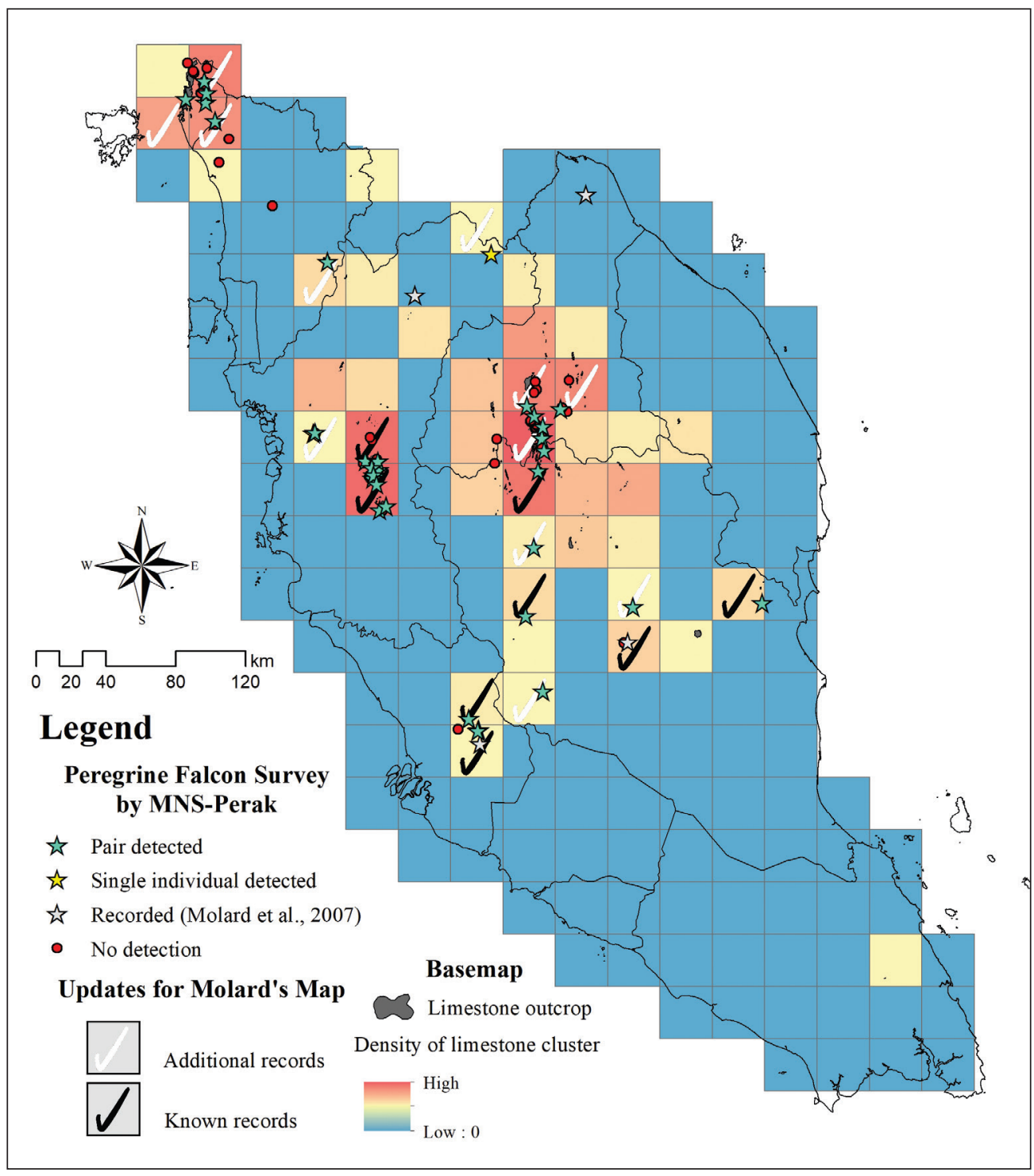

Figure 4. Map showing the currently known breeding distribution of Falco peregrinus ernesti in West Malaysia. It shows the combined results of the MNS Perak Peregrine Falcon Survey team during 2017-2019 and compares the progress of our knowledge with one decade earlier, when Laurent Molard conducted intensive surveys in partly the same region. The relative area of limestone outcrops, the major breeding habitat of peregrines here, is shown per $20 \times 20 \mathrm{~km}$ square (from Liew et al. 2016)

4. ábra A térkép az F. p. ernesti alfaj jelenleg ismert költési eloszlását mutatja Nyugat-Malajzia területén. A térképen az MNS Perak Peregrine Falcon Survey kutatócsoport 2017-2019-es felméréseinek összeredménye szerepel az egy évtizeddel azelőtti, Laurent Molard által részben ugyanabban a régióban végzett felmérés eredményeivel összehasonlítva. A mészkőkibúvások relatív területét, ahol a vándorsólymok költőhelyének legnagyobb része található, 20×20 km-es négyzethálón ábrázoltuk (Liew et al. 2016 alapján) 
observations into a context and make some additional comments especially on our most thorough survey, that in January 2019. We also discuss our use of call playback in peregrine surveys, which we have found to be fairly controversial when we discussed it with colleagues.

Our surveys, along with previous work in Malaysia especially by Laurent Molard, represent one of only a small handful of population studies of the peregrine in a tropical country. Thus, we think that we cover uncharted territory even by providing such basic information about the West Malaysia birds as nesting density, population size and timing of breeding.

National population size and density: Currently, the known total of confirmed or suspected peregrine breeding sites in West Malaysia is 36. Molard et al. (2007) put forward a population estimate of 70-80 pairs for all limestone cliffs in the $135,000 \mathrm{~km}^{2}$ area of Peninsular Malaysia, i.e. $0.05-0.06$ pairs per $100 \mathrm{~km}^{2}$. Hence, we currently stand at about half of the projection by Molard et al. (2007). Looking at the maps of the known distribution in that publication and at our maps in Figures 2 and 4, one may get the impression that perhaps this earlier estimate was a little bit too optimistic? Most areas of Malaysia are flat and devoid of any limestone cliffs or useable (big) quarries and we have now surveyed all major regions of West Malaysia where cliffs occur in any greater number, i.e. the regions around Ipoh and Gua Musang and the state of Perlis. With few exceptions (in part due to lack of accessibility by road), we believe that during our surveys we have checked at least once all major cliffs in the regions visited if they were further apart from known pairs than about 2 kilometres, and hence could have held an additional pair. However, we do not know how many cliffs we have not even seen, mostly because they may have been outside of sight from any reasonable road. As a result, we would not feel comfortable to make an updated population size estimate based on some guesstimate of the proportion of suitable nesting cliffs that we have visited.

However, we plan to conduct future surveys to obtain a (much) more complete picture of the distribution and population density of peregrines in West Malaysia. This will also include in-depth study of aerial maps in Google Earth to try and identify all promising limestone hills in the country. It will also include the study of all available other information, including sightings in eBird for instance.

Compared to many parts of the world, the peregrine seems to be extremely rare in Malaysia. In the best, high-density areas in Europe such as the French Jura mountains, population density is between 1 and 2 pairs per $100 \mathrm{~km}^{2}$ (Monneret et al. 2018), i.e. about 27 times greater than what Molard et al. (2007) suggests for West Malaysia. During our survey, the minimum nearest-neighbour distance was just under $4 \mathrm{~km}$ (with the exception of one case of two possible pairs at a distance of only $2 \mathrm{~km}$ near Ipoh in 2017, see Kéry et al. 2017). More often than not, pairs in Malaysia appear to be isolated by many kilometres from the nearest neighbouring site. This is again in stark contrast to high-density populations in temperate and cold latitudes where, for instance in the French Jura, nearest-neighbour distances of $1-2 \mathrm{~km}$ are not rare.

In addition, it was remarkable that during the three surveys so far, with many dozen visits to occupied sites, we have observed intruding peregrines only once or twice, and we never observed any immature peregrines during the entire survey. In contrast, in high-density 
populations, e.g. in the Jura, during the same stage in the breeding cycle (i.e. when courtship is most intense, just before egg-laying), intruding birds can be seen during most full days of surveying, including often immatures (i.e. $2 \mathrm{CY}$ birds).

In summary, the peregrine seems to be a fairly widespread, but overall extremely rare breeding bird in West Malaysia. It currently appears to be almost completely limited by the occurrence of tall limestone cliffs. It is our impression that the peregrine only inhabits very tall cliffs in Malaysia compared to many other parts of the world where we have observed it (e.g. Europe, South America, Australia, pers. obs. by MK), where the species accepts much smaller cliffs as well. We have seen a great many first-class cliffs (Ratcliffe 1993) in Malaysia that, if they were in some of these other countries, would be bound to have a pair, but they are unoccupied here. We wonder whether this is simply because of the generally much smaller density or for some other reasons?

One possible reason for the apparently much greater selectivity of peregrines for tall and vertical cliffs in Malaysia may be the risk of predation by monkeys. Several species of monkeys occur in the country and they are formidable climbers, either on the cliff-face itself, or especially if there is any vegetation growing in the cliff-face. In this latter case, monkeys may drop from bush to bush to reach many places even in a vertical or overhung crag. For instance, at one of the historically known peregrine cliffs mentioned in Molard (2005), which we visited in 2019 and which was the only known territory where we failed to see any peregrines during that survey, we once saw a large group of monkeys that were virtually "abseiling" vertically down through the tall cliff, dropping from one bush in the cliff to the next one down, over jump distances of 5-10 $\mathrm{m}$. Some parts of the vertical cliff were climbed downwards "nakedly", without the aid of any vegetation. And it has to be said that the very rich texture of many tropical karst cliffs may provide many good grips for climbing monkeys. Hence, we hypothesize that perhaps monkeys represent an important selection pressure for West Malaysia peregrines to nest only in the tallest and most vertical cliffs. There are certainly reports that pairs in smaller nesting cliffs failed and this was attributed to predation by monkeys (Chong 2002, Noack 2002).

Timing of breeding: Our observations confirm what Molard et al. (2007) say about the timing of breeding in Malaysia: "Egg-laying seems to occur from the end of January to the beginning of February". During the 2019 survey, we observed at least 8 females spend long times in and at the edge of possible eyrie sites, and in some cases they came out and very soon disappeared again into such sites when we used playback. All this seemed to indicate that they were either about to start laying or already had some eggs. Since the courtship period is the best period in the annual cycle to survey a population for occupancy, and courtship is most intense just before egg-laying, it is clear that peregrine surveys in West Malaysia should not take place after January if the aim is to focus on the number of occupied sites.

Use of whitewash in peregrine surveying: Whitewash (i.e. feces or droppings) in a cliff provides one of the most important hints for occupancy of a site by peregrines (or indeed, most other species of cliff-nesting raptors). Whitewash identification is not an exact science though, and depending on the variety of cliff-nesting species, it may be pretty useless as a 
pointer to peregrines occupying a site in some regions of the world. However, when large cliff-nesting birds other than peregrines are rare or absent, it may be very important. Malaysia does not have many large bird species that live in cliffs, and hence, whitewash can be very informative in peregrine surveys (if one learns to distinguish the longer and broader streaks produced by a peregrine from the much thinner and shorter streaks produced for instance by cliff-dwelling starlings and mynahs). Nevertheless, our observations during the 2019 survey reminded us that the Barn Owl (Tyto alba) is probably a widespread species that also nests in cliffs and it does produce whitewash that can look pretty much like that of a peregrine. Thus, caution is required when trying to predict from white-wash the occupancy of peregrines at a site.

Use of playback in peregrine surveying: Our 2019 survey was the first time that we made large-scale use of playback calls of the 'eee-chup' courtship call, played from a strong gamecall player. This frequently enticed birds to become airborne and to call themselves, typically also giving the 'eee-chup' call. Sometimes, this made detection of a pair very simple even at very large cliffs and with less than optimal visibility (e.g. with strong glare or observing a cliff with the sun in the eyes). About two thirds of all recorded pairs were first detected as a response of the birds' reaction to the playback. And although we drove almost twice as much during the 2019 survey as during the previous survey in 2018 (3,000 vs. 1,600 km), our use of playback was surely in part responsible for us finding more than twice as many occupied sites during the 2019 survey than during the 2018 survey (28 vs. 13). Hence, use of playback can work wonders when conducting peregrine surveys, and we have the impression that this does not seem to have been widely known in the peregrine community worldwide (pers. comm. of several colleagues to MK). This is somewhat surprising, given that the efficacy of playback in peregrine survey work has been described in at least two publications so far (Barnes et al. 2012, Ambrose et al. 2014).

However, playback may have possible drawbacks and it has been severely criticized by many observers (peregrine or otherwise), because (1) it is sometimes feared to be a serious disturbance of the birds and (2) it may also be very intrusive for a romantic feel of the observer as being in some sort of unity with the environment and the birds. We think that both concerns are valid and must be addressed seriously.

Playback of the eee-chup call simulates the soundtrack of an intruding peregrine and hence, the attending birds react in a strongly aggressive manner, by flying off, calling and alighting at exposed places (such as the cliff top or trees there) presumably to better spot the apparent intruders as well as signaling to them the presence of a territory-holder. Interestingly, it is our impression that the females reacted much more predictably to the playback than did the tiercels, even though our recording was of a pair.

During our 2019 survey, we played the eee-chup calls at a site for a maximum of 2.6 minutes and stopped as soon as we had detected the pair, in order to minimize disturbance; hence, often we stopped after only 10-20 seconds. At most sites, the observable reaction to the disturbance by the attending birds, i.e. flying and calling, ceased already a few minutes after the playback, flying usually immediately after 1-2 changes of position of the birds and calling a little later. 
Our use of playback simulates a natural event (intrusion of another bird into the territory), which will regularly occur during the pre-breeding season, when territories are staked out anew: attending birds will ascertain their claim to their territory and recruits will try to find a new territory, and a mate, to breed. Clearly, peregrines have evolved to deal with this type of disturbance, because it must happen frequently every year in all but the most isolated territories. Even in a very low-density population such as the one in West Malaysia (see above), over the course of a courtship period of between 4 and 6 weeks, we think that it is unlikely that any pair will ever be spared of the experience of an intruder.

Thus, we think that our use of playback in a systematic, large-scale survey will have represented an overall very slight disturbance only and one that is very unlikely to cause any effects on the survival or reproduction of the birds, nor on their decision to stay on the territory or leave it. But it has to be admitted that at the current time, with the current data, this statement has the nature of a mere hypothesis, and it should be tested and confronted with empirical data. That is, it would be valuable to test this hypothesis and corroborate or refute it by quantitative measurements of breeding success and future site occupancy. For instance, it would be important to compare breeding success and local site extinction probability between two groups of sites: one group of sites where there was some playback during the breeding season and another group of sites where there was not. Due to the scarcity of the peregrine in Malaysia, such a controlled experiment would best be conducted in another part of the world where the population densities are much higher.

The second argument that we have heard being made against the use of playback when surveying peregrines is that it destroys some romantic feeling when being in the field, sometimes in very beautiful and almost pristine-looking areas: indeed, it can be a disturbing feeling when suddenly there is that strong "noise" produced in a beautiful area. Actually, we feel the same: i.e. we think that emotionally, for us as observers, use of playback goes against a more romantic approach to peregrine watching where we look for watching the birds in beautiful, natural and quiet environments. However, we are of the opinion that if playback does not have any lasting negative effects on the birds, it is up to each individual observer to decide whether s/he does or does not want to make use of this much improved detection method. This decision will also likely depend on the goals of the observations: if observations are made as part of a more systematic survey of some larger region, then we think use of playback can be a great thing to make these surveys much more efficient ... and the data collected much more complete and reliable. Otherwise, if observations are made for pleasure only, to rejoice in watching the birds and their behaviour, then we think that use of playback should be avoided. Also, playback should not be used at a site where occupancy has already been ascertained during earlier visits of the same breeding season. We would certainly not endorse use of playback for peregrine photography.

In summary, we have found (as did Barnes et al. 2012 and Ambrose et al. 2014), that peregrines can react very reliably to the use of playback, mostly of the eee-chup call, and clearly, that this can greatly increase the scope and efficiency of a survey. We believe that minimal use of playback (as we did, and not more than 1-2 times per breeding season and site) does not cause any lasting negative effects on the birds, but we caution that there is currently no evidence for or against this hypothesis. This hypothesis should be tested and if serious 
effects of playback in one season are found (e.g. when birds are more likely to fail a breeding attempt, brood size is reduced or the likelihood that a site is abandoned during the following breeding season), use of playback should be stopped for peregrines.

\section{Outlook}

Despite being one of the world's most widespread bird, the peregrine is almost exclusively studied outside of the tropics. Malaysia is one of the very rare tropical countries where some basic information on the population ecology of the peregrine has been collected. In addition, many occupied sites are in danger of being erased by quarry operations that feed the relentless construction boom in Malaysia and other SE Asian countries. Therefore, we argue that there is a considerable scientific and conservation need for further surveys to better know the situation of breeding Peregrine Falcons in Malaysia.

Thus, studies such as ours gain particular value by their relative uniqueness as a population study of the peregrine in the tropics. In the future, we plan to improve our knowledge about distribution and density of the peregrine in West Malaysia by repeating our surveys. This need not happen every year, and a biennial rhythm may be enough detect longer-term trends as well as to further accumulate knowledge about the distribution of the species. In addition, it would be interesting to not only collect information about distribution and density of the population, but also about its productivity, by conducting surveys in April and May to count fledged young.

Currently, peregrines in West Malaysia appear to nest almost exclusively in cliffs and these can sometimes be picked out quite well from aerial photographs in Google Earth. But peregrines have also been found as nesters on buildings (see Molard et al. 2007), and the worldwide trend towards increased prevalence of this type of nesting habitat suggests to us to be vigilant for an increase of peregrines nesting on buildings also in Malaysia and perhaps including also tall transmission towers.

\section{Remembrance}

This article is meant in part to be a remembrance for the first author, our dear and admired colleague and friend Ooi Beng Yean. Beng passed away barely 1 month after our 2019 peregrine survey, on 2 March 2019 in Sabah, while doing what he perhaps liked to do best: bird-watching in the company of his friends. We plan to continue our surveys, but we know that without Beng, it will never be the same.

\section{Acknowledgements}

We warmly thank the Tan Kean Cheong Bird Conservation Memorial Fund (TKCBCMF) of the MNS Perak for a grant to cover our expenses incurred for food, lodging and mileage 
during the 2018 and 2019 survey. We are also very grateful to Connie Khoo for many helpful and interesting exchanges over the years. Finally, we thank Su Ping Ong, Puan Chong Leong, Henry Goh, and Gerry and Joy Danen who all joined us for some days on the 2017 survey, and Lim Kim Chye and Lim Swee Yian who did the same during our 2019 survey. We also thank the editor and two referees for their valuable suggestions that improved and clarified our paper.

\section{References}

Ambrose, S., Ritchie, R. J. \& Florian, C. 2014. Use of and responses to audio survey technique by Peregrine Falcons in Alaska. - Northwestern Naturalist 95: 125-128. DOI: 10.1898/NWN13-33.1

Barnes, J. G., Jaeger, J. R. \& Thompson, D. B. 2012. Effectiveness of call-broadcast surveys to detect territorial Peregrine Falcons. - Journal of Raptor Research 46(4): 365-377. DOI: 10.3356/JRR-11-61.1

Chiu, S. C., Ooi, B. Y. \& Khoo, C. S. Y. 2006. Observations on nesting Peregrine Falcon Falco peregrinus in Perak. - Suara Enggang 14(3): 11-15.

Chong, M. H. N. 2002. Peregrine Falcon Falco peregrinus ernesti nesting at Temengor Forest Reserve, Perak, in February 1996: a first successful breeding record for Malaysia. - Asian Raptor Bulletin 3: 19-20.

Döttlinger, H. 2002. The Black Shaheen Falcon (Falco peregrinus peregrinator Sundevall 1837): its morphology, geographic variation and the history and ecology of the Sri Lanka (Ceylon) population. - PhD Thesis, University of Kent, UK.

Döttlinger, H. \& Hoffmann, T. W. 1999. Status of the Black Shaheen or Indian Peregrine Falcon (Falco peregrinus peregrinator) in Sri Lanka. - Journal of the Bombay Natural History Society 96(2): 239-243.

Döttlinger, H. \& Nicholls, M. 2005. Distribution and population trends of the 'black shaheen' Peregrine Falcon Falco peregrinus peregrinator and the eastern Peregrine Falcon F. p. calidus in Sri Lanka. - Forktail 21: $133-138$.

Döttlinger, H., Nicholls, M. K. \& Attapattu, N. 1999. The Black Shaheen (Falco peregrinus peregrinator) in Sri Lanka - a report of the 1997 field season. - Falco 13: 15-18.

Kéry, M. 2002. New observations of the Peregrine Falcon (Falco peregrinus) in Peru. - Journal of Raptor Research 36: 213-217.

Kéry, M., Chiu, S. C., Ooi, B. Y., Percival, R. C., Ong, S. P. \& Puan, L. C. 2017. Malaysian Peregrine Falcon Survey Report 2017. - Report, Swiss Ornithological Institute, Sempach, Switzerland, pp. 1-86.

Kéry, M., Chiu, S. C., Ooi, B.Y. \& Percival, R. C. 2018. Malaysian Peregrine Falcon Survey Report 2018. - Report, Swiss Ornithological Institute, Sempach, Switzerland, pp. 1-92.

Liew, T-S., Price, L. \& Clements, G. R. 2016. Using Google Earth to improve the management of threatened limestone karst ecosystems in Peninsular Malaysia. - Tropical Conservation Science 9(2): 903-920. DOI: 10.1177/194008291600900219

Molard, L. 2005. Atlas of Peregrine Falcon Falco peregrinus ernesti sites in Peninsular Malaysia. - Unpublished report

Molard, L., Kéry, M. \& White, C. M. 2007. Estimating the resident population size of Peregrine Falcon Falco peregrinus in Peninsular Malaysia. - Forktail 23: 87-91.

Molard, L. 2009. Behaviour and ecology of resident Peninsular Malaysia Peregrine Falcons. - In: Sielicki, J. \& Mizera, T. (eds.) Peregrine Falcon Populations - Status and Perspectives in the $21^{\text {st }}$ century. - Turul/Poznan University of Life Sciences Press, Poznan, pp. 479-492.

Monneret, R-J., Ruffinoni, R., Parish, D., Pinaud, D. \& Kéry, M. 2018. The Peregrine population study in the French Jura mountains 1964-2016: use of occupancy modeling to estimate population size and analyze site persistence and colonization rates. - Ornis Hungarica 26: 69-90. DOI: 10.1515/orhu-2018-0016

Noack, F. 2002. Breeding Peregrine Falcons in Perlis State Park. - Suara Enggang 2: 18-19.

Ooi, B. Y., Kéry, M., Percival, R. C., Lee, Z. H. \& Chiu, S. C. 2019. Malaysian Peregrine Falcon Survey Report 2019. - Report, Swiss Ornithological Institute, Sempach, Switzerland, pp. 1-126.

Ratcliffe, D. A. 1993. The Peregrine Falcon, $2^{\text {nd }}$ edition. - T \& AD Poyser, London

White, C. M., Cade, T. J. \& Enderson, J. H. 2013. Peregrine Falcons of the world. - Lynx Editions, Barcelona 